\title{
PREVALENCE OF HYPERTENSION AND ITS ASSOCIATION WITH VITAL STATICS OF ADULTS AMONG URBAN, SEMIURBAN, RURAL AREAS OF UTTARAKHAND
}

\author{
VINITA THAPLIYAL ${ }^{1}$, KARUNA SINGH ${ }^{2}$, ANIL JOSHI ${ }^{2}$
}

${ }^{1}$ Research Scholar, Amity Institute of Food Technology, Amity University, Noida, Uttar Pradesh, India. ${ }^{2}$ Assistant Professor-III, Amity Institute of Food Technology, Amity University, Noida, Uttar Pradesh, India. ${ }^{3}$ Director, Himalayan Environmental Studies and Conservation Organization (HESCO). Email: Vinita.thapliyal22@gmail.com

Received: 21 May 2018, Revised and Accepted: 14 JUne 2018

ABSTRACT

Objective: India is in the affirmed phase of evolution and transition, demographic, economic, epidemiological, and nutrition transition. Moreover, all these transitions are leading non-communicable diseases such as obesity, hypertension, and insulin resistance. The study was aimed to estimate the prevalence of hypertension and its association with vital statics of adults among urban, semiurban, rural areas of Sub-Himalayan Region.

Methods: A cross sectional community based study was done, using WHO step questionnaire. A survey was conducted in urban, semi urban, Rural areas of Uttrakhand, to make a sample size of 300 adults (18-45yr), 100 from each zone. Blood pressure and body mass index (BMI) of the participants was calculated. $\mathrm{p}<0.05$ was considered statistically significant.

Results: In the sample population based on systolic BP, $61.3 \%$ were non-hypertensives, $29.7 \%$ were pre-hypertensives, and $9 \%$ were hypertensives. Based on diastolic BP, $43.3 \%$ were non-hypertensives, $32.7 \%$ were pre-hypertensives, and 24\% were hypertensives. Participants with hypertension and pre-hypertension have higher BMI and waist circumference.

Conclusion: A high prevalence rate of pre-hypertension and hypertension was depicted in urban, semiurban, and rural areas of the sub-Himalayan region. $4.8 \%$ of the female participants had systolic high blood pressure compared to the $11.9 \%$ of the male participants. On the other hand, $21.8 \%$ of the female participants had diastolic high blood pressure compared to the over $25 \%$ of the male participants. Dehradun has the highest rates of high blood pressure while Rudraprayag has the lowest. BMI was significantly correlated with systolic BP in Dehradun adults (p<0.05). Diastolic BP was significantly positively correlated with age and BMI in Dehradun adults $(\mathrm{p}<0.05)$. Age was positively significantly correlated with pulse rate in Dehradun and Uttarkashi adults $(\mathrm{p}<0.05)$. In Rudraprayag adults, weight was significantly positively correlated with both systolic and diastolic BP $(\mathrm{p}<0.05)$. No other correlations were seen in anthropometry and vital statistics of Rudraprayag or Uttarkashi adults ( $\mathrm{p}>0.05)$.

Key words: Body mass index, Hypertension, WHO step questionnaire.

(c) 2018 The Authors. Published by Innovare Academic Sciences Pvt Ltd. This is an open access article under the CC BY license (http://creativecommons. org/licenses/by/4. 0/) DOI: http://dx.doi.org/10.22159/ajpcr.2018.v11i10.27449

\section{INTRODUCTION}

India is suffering from the twin trouble of undernutrition and the swift steady boost in the outbreak of non-communicable disease (NCD). In 2002, NCDs were the cause for $60 \%$ deaths and $43 \%$ of diseases globally by the year 2020 , it is roughly estimated to affect for about $73 \%$ deaths and $60 \%$ burden of disease burden [1,2]. NCDs are anticipated to cause death to almost double, that is, from approximately 4 million to 8 million from the year 1990 to 2020 in India [2,3]. The key factors of increasing burden of NCDs in India are urbanization, nutrition transition, globalization, and economic growth. Rapid urbanization leads to pitiable dietary practices and lifestyle with low physical activity. In India, approximately $28 \%$ of the total population was living in urban areas in 2001, with an estimation of about 50\%, with 605-618 million by 2021-2025 [2-4]. The growth in the urban population is not uniform and demographic trend shows that the growth rate in the urban was stabilized at $3 \%$ over the past decade (1991-2001), whereas the growth rate of the slum gets double at 5-6\% [5]. Urban poor faced two worst ends; first, modern lifestyle (which makes them at risk of degenerative diseases) and second, poverty (which cause low healthcare purchasing capability).

Uttrakhand is a newly developed state of India which is at the nascent stage of development. It is geographically, ecologically feeble, economically unformed, and densely populated mountain ecosystem. With swift growing urbanization and development of infrastructure, connectivity to the villages is more and therefore area has undergone urbanization in a speedy way and with this, there is easy access to markets. Hence, major area of cultivated land and are being used for more infrastructure expansion, services activities, and economic activities in the hilly region $[5,6]$ There is a reasonable regional transition from farming of traditional crop and animal husbandry system to locally yielded vegetables, fruits, and milk for sale in townified, urban locale. This affects the conventional land use model. The shift in the pattern of physical activity and dietary changes is the main reason of demographic and socioeconomic changes [6].

Uttarakhand is a diverse state with varied terrains and compact population density in the plain region. Demographic shift is pointing a transition in population dynamics homologs with socioeconomic growth (i.e., rising economies, education, employment, improvement in health status, and life expectancy and changes in lifestyle). This has been coincided by an epidemiological shift $[7,8]$. Despite the boost in life expectancy, there is a sturdy growth in chronic diseases of aging and life-styles related diseases such as hypertension, stroke, diabetes, and other cardiovascular diseases. The various studies have shown the emergence of the epidemiological shift has often been linked with epidemics of degenerative heart diseases (including hypertension, ischemic heart diseases, and cardiovascular disease), type 2 diabetes mellitus, and other chronic diseases [9].

Weather conditions result in various contradictory lifestyle practice and lead to practices such as smoking, tobacco consumption, alcohol 
consumption, and consumption of fruits and vegetables not grown locally $[10,11]$. This gives rise to a high prevalence rate of NCDs $[6,12]$.

The study was undertaken to find the prevalence and associated risk factors of hypertension and also association of changes in lifestyle practices such as smoking and alcohol consumption, with various other vital statistics among the study population. The study would aid in generating the data regarding obesity and hypertension in a rural area and hence would initiate timely precautionary measures to reduce the adverse health effects.

\section{METHODS}

A survey was conducted in three zones of Uttarakhand state (Uttarkashi, Rudraprayag, Dehradun) representing the rural, semirural, and urban village population of the state to make a sample size of 300,100 adults were selected from each of the 3 zones, respectively. One man and woman from eligible age groups of each household were selected and visited personally. Random selection was done if there is more than one eligible candidate present in a particular household.

\section{Data collection}

The data collection was done using the WHO STEPS questionnaire approach. Interview technique was used by the investigator for the collection of data. Confidentiality of the information was ensured and written consent form was filled. Anthropometric measurements and variables such as weight (kilograms) using Karda digital weighing scale, height (centimeters) using stadiometer and (waist circumference [WC] in centimeters) were recorded using standard procedures were measured in a separate room. Body mass index (BMI) $\left(\mathrm{kg} / \mathrm{m}^{2}\right)$ was calculated [13]. The latest classification of BMI for Asian populations was used to define overweight (23-24.99 $\left.\mathrm{kg} / \mathrm{m}^{2}\right)$ and obesity $\left(>25 \mathrm{~kg} / \mathrm{m}^{2}\right)$ [14]. WC in men and women was taken as high and used to define central obesity [15].

Blood pressure was measured using a mercury sphygmomanometer. Two readings of blood pressure were taken of the subject sitting in a relaxed sitting and average of both reading was taken. Hypertension was classified using JNC-8 criteria [16].

Analysis was carried out using SPSS version 17.0. Pearson's Chi-square test was used to evaluate differences between groups for categorized variables. Normally distributed data were $90 \%$ confidence intervals.

\section{Sample size}

The sample size calculated was 269 with confidence interval of $90 \%$ and margin of error $5 \%$. Formula used for the calculation is as under:

Sample size $=\frac{\mathrm{z} 2 \times \mathrm{p}(1-\mathrm{p})}{\mathrm{e} 2}$

$$
\frac{1+(\mathrm{z} 2 \times \mathrm{p}(1-\mathrm{p})}{\mathrm{e} 2 \mathrm{~N}}
$$

where

$\mathrm{N}=$ Population size

$\mathrm{e}=$ Margin of error

$\mathrm{Z}=\mathrm{z}$ score.

The calculated sample size was 269 , but a total of 300 participants were included for the study. Written consent was obtained from each study participant.

\section{Data analysis}

The analysis was done using SPSS 17 computer statistical software package. To find the relationship with categorical variables, frequency distribution and cross-tabulation were done. The Chi-square test was used and level of significance was $0.05(\mathrm{p}<0.05)$.

\section{RESULTS}

For the study, 100 adults were selected from each of the 3 zones (Uttarkashi, Rudraprayag, and Dehradun). Table 1 shows the sociodemographic profile of the subject. Out of the 300 adults, $176(58.7 \%)$ were male whereas 124 (41.3\%) were female. The mean age of males from Dehradun, Rudraprayag, Uttarkashi were 31.5 \pm 8.1 , $36.9 \pm 8.7$, and $33.1 \pm 9.1$ respectively. Whereas, the mean age of females from Dehradun, Rudraprayag, and Uttarkashi were 33.6 $\pm 7.9,36.8 \pm 8.4$, and $34.2 \pm 10.1$ respectively. The literacy level of the population was $96 \%$ whereas $4 \%$ population has never attended school. The mean year of schooling was least in Uttarkashi zone $(\mathrm{p}<0.001)$.

Table 2 shows the modifiable risk factors of the study group. Various modifiable risk factors analyzed were smoking of tobacco products, smokeless tobacco, alcohol consumption, fruits and vegetable consumption, history of diabetes, BMI, and WC.

Table 3 depicted the correlation of age and anthropometry with vital statistics when classified according to zone. BMI was significantly correlated with systolic BP in Dehradun adults $(\mathrm{p}<0.05)$. Diastolic BP was significantly positively correlated with age and BMI in Dehradun adults $(\mathrm{p}<0.05)$. Age was positively significantly correlated with pulse rate in Dehradun and Uttarkashi adults $(\mathrm{p}<0.05)$. In Rudraprayag adults, weight was significantly positively correlated with both systolic and diastolic BP $(\mathrm{p}<0.05)$

Table 4 depicted the regression analysis which shows the presence or absence of hypertension as the dependent variable and age, BMI, vegetable intake frequency, use of alcohol, smoking, the and presence of diabetes as independent variables. Analysis revealed that in the population of Dehradun, BMI was significantly associated with

Table 1: Sociodemographic characteristics of the study subjects

\begin{tabular}{|c|c|c|c|}
\hline \multirow[t]{2}{*}{ Variable } & \multicolumn{3}{|l|}{ Zone } \\
\hline & Dehradun (\%) & Rudraprayag & Uttarkashi \\
\hline \multicolumn{4}{|l|}{ Sex } \\
\hline Male & 66 & 59 & 51 \\
\hline Female & 34 & 41 & 49 \\
\hline \multicolumn{4}{|l|}{ Age } \\
\hline Male & $31.5 \pm 8.1$ & $36.9 \pm 8.7$ & $33.1 \pm 9.1$ \\
\hline Female & $33.6 \pm 7.9$ & $36.8 \pm 8.4$ & $34.2 \pm 10.1$ \\
\hline \multicolumn{4}{|l|}{ Religion } \\
\hline Hindu & 85 & 100 & 100 \\
\hline Muslim & 8 & - & - \\
\hline Sikh & 7 & - & - \\
\hline \multicolumn{4}{|l|}{ Marital status } \\
\hline Married & 62 & 92 & 71 \\
\hline Unmarried & 36 & 6 & 23 \\
\hline Divorced & 2 & 2 & 6 \\
\hline \multicolumn{4}{|l|}{ Education level } \\
\hline $\begin{array}{l}\text { No formal } \\
\text { education }\end{array}$ & - & - & - \\
\hline $\begin{array}{l}\text { Less than } \\
\text { primary }\end{array}$ & - & 1 & 2 \\
\hline $\begin{array}{l}\text { Primary } \\
\text { complete }\end{array}$ & - & 18.6 & 15.2 \\
\hline $\begin{array}{l}\text { Secondary } \\
\text { school }\end{array}$ & 5 & 18.6 & 12.1 \\
\hline $\begin{array}{l}\text { High school } \\
\text { complete }\end{array}$ & 37 & 39.2 & 38.4 \\
\hline Graduation & 41 & 8.2 & 24.2 \\
\hline Post-graduation & 16 & 13.4 & 7.1 \\
\hline \multicolumn{4}{|l|}{ Type of house } \\
\hline Pakka & 100 & 92 & 79 \\
\hline Semi Pakka & - & 3 & 15 \\
\hline Kaccha & - & 3 & 7 \\
\hline
\end{tabular}


Table 2: Modifiable risk factor of the study subjects

\begin{tabular}{|c|c|c|c|c|c|c|}
\hline \multirow[t]{2}{*}{ Variable } & \multicolumn{3}{|l|}{ Men } & \multicolumn{3}{|l|}{ Women } \\
\hline & $\begin{array}{l}\text { Dehradun } \\
n=66(\%)\end{array}$ & $\begin{array}{l}\text { Rudraprayag } \\
n=59(\%)\end{array}$ & $\begin{array}{l}\text { Uttarkashi } \\
n=51(\%)\end{array}$ & $\begin{array}{l}\text { Dehradun } \\
n=34(\%)\end{array}$ & $\begin{array}{l}\text { Rudraprayag } \\
n=41(\%)\end{array}$ & $\begin{array}{l}\text { Uttarkashi } \\
\mathrm{n}=49(\%)\end{array}$ \\
\hline Smokeless tobacco & 13.6 & 27.1 & 15.7 & - & - & - \\
\hline Alcohol consumption & 45.5 & 35.7 & 49 & - & - & 1.7 \\
\hline 7 days consumption of vegetable & 57.6 & 96.6 & 68.6 & 76.5 & 90.2 & 57 \\
\hline 7 days consumption of fruits & 6.1 & 59.6 & 6 & 8.8 & 46.3 & 6.4 \\
\hline History of diabetes & 13.6 & 3.6 & 9.8 & 8.8 & - & 8.2 \\
\hline $\mathrm{BMI}$ & $24.5 \pm 2.1$ & $23.4 \pm 3.3$ & $22.8 \pm 2.9$ & $25.7 \pm 2.7$ & $23.9 \pm 3.0$ & $22.5 \pm 1.9$ \\
\hline WC $(\mathrm{cm})$ & $88.5 \pm 9.0$ & $86.0 \pm 10.4$ & $85.4 \pm 8.2$ & $89.8 \pm 13.9$ & $78.8 \pm 10.9$ & $78.8 \pm 6.0$ \\
\hline
\end{tabular}

Data presented as mean \pm SD and percentage. WC: Waist circumference

Table 3: Correlation of age and anthropometry with vital statistics when classified according to zone

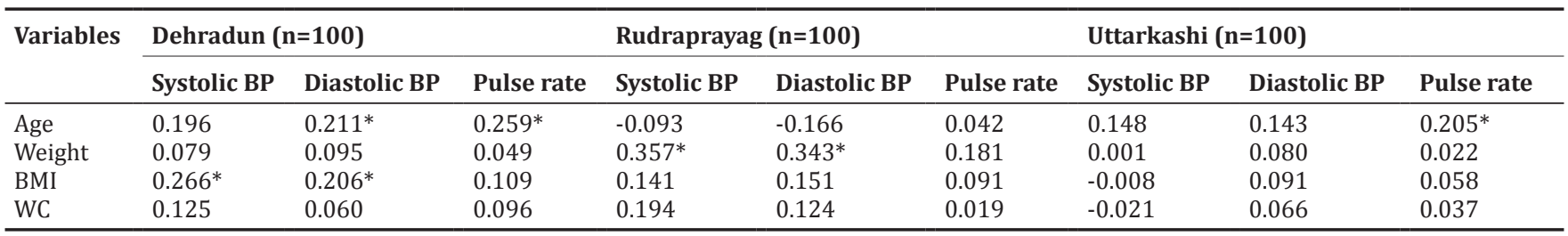

Data presented as Pearson correlation value. ${ }^{*} \mathrm{p}<0.05$. WC: Waist circumference

Table 4: Multivariate analysis for risk factor of hypertension

\begin{tabular}{|c|c|c|c|}
\hline \multicolumn{4}{|c|}{ Variables in the equation } \\
\hline \multirow[t]{2}{*}{ Zone } & \multirow[t]{2}{*}{$\operatorname{Exp}(B)$} & \multicolumn{2}{|c|}{ 95.0\% CI for EXP (B) } \\
\hline & & Lower & Upper \\
\hline \multicolumn{4}{|l|}{$\begin{array}{l}\text { Dehradun } \\
\text { Step } 1^{\mathrm{a}}\end{array}$} \\
\hline Gender (1) & 1.730 & 0.528 & 5.663 \\
\hline Age & 1.001 & 0.931 & 1.075 \\
\hline Diabetes (1) & 1.171 & 0.299 & 4.586 \\
\hline Smoking (1) & 0.548 & 0.046 & 6.555 \\
\hline $\begin{array}{l}\text { Alcohol_12_- } \\
\text { months (1) }\end{array}$ & 2.145 & 0.180 & 25.603 \\
\hline BMI & 1.311 & 1.035 & 1.662 \\
\hline veg_freq_code (1) & 2.930 & 0.284 & 30.271 \\
\hline Constant & 0.001 & & \\
\hline \multicolumn{4}{|l|}{ Rudrapryag } \\
\hline \multicolumn{4}{|l|}{ Step $1^{\mathrm{a}}$} \\
\hline Gender (1) & 1.933 & 0.697 & 5.362 \\
\hline Age & 0.963 & 0.914 & 1.015 \\
\hline Diabetes (1) & $3.205 E 9$ & 0.000 & \\
\hline Smoking (1) & 0.487 & 0.092 & 2.572 \\
\hline $\begin{array}{l}\text { Alcohol_12_- } \\
\text { months (1) }\end{array}$ & 0.802 & 0.150 & 4.294 \\
\hline BMI & 1.022 & 0.886 & 1.177 \\
\hline Veg_freq (1) & 0.497 & 0.040 & 6.238 \\
\hline Constant & 2.360 & & \\
\hline \multicolumn{4}{|l|}{ Uttarkashi } \\
\hline \multicolumn{4}{|l|}{ Step $1^{\mathrm{a}}$} \\
\hline Gender (1) & 2.305 & 0.634 & 8.388 \\
\hline Age & 1.014 & 0.960 & 1.072 \\
\hline Diabetes (1) & 1.584 & 0.274 & 9.161 \\
\hline Smoking (1) & 1.854 & 0.395 & 8.692 \\
\hline $\begin{array}{l}\text { Alcohol_12_- } \\
\text { months (1) }\end{array}$ & 1.117 & 0.233 & 5.358 \\
\hline BMI & 1.249 & 0.972 & 1.604 \\
\hline Veg_freq_code (1) & 1.124 & 0.080 & 15.839 \\
\hline Constant & 0.005 & & \\
\hline
\end{tabular}

aVariables entered on step 1: Gender, age, diabetes, smoke, alcohol_12_months, BMI, veg_freq_code

hypertension in Dehradun (OR 1.311, 95\% CI; 1.035-1.662) and Uttarkashi (OR 1.249, 95\% CI; 0.972-1.604). BMI was significantly correlated with systolic BP in Dehradun adults $(\mathrm{p}<0.05)$. Diastolic BP was significantly positively correlated with age and BMI in Dehradun adults $(\mathrm{p}<0.05)$. Age was positively significantly correlated with pulse rate in Dehradun and Uttarkashi adults $(\mathrm{p}<0.05)$. In Rudraprayag adults, weight was significantly positively correlated with both systolic and diastolic BP $(\mathrm{p}<0.05)$. No other correlations were seen in anthropometry and vital statistics of Rudraprayag or Uttarkashi adults ( $p>0.05)$. Thus, in Dehradun and Uttarkashi, with higher BMI, the risk of hypertension increases by 1.3 times.

\section{DISCUSSION AND CONCLUSION}

The study verified the prevalence of hypertension which was radically high among adults. A study by Vasan et al. shows a positive alliance of hypertension with age [17]. The present study shows the inaptly high rates of hypertension and BMI were detected among the population of the rural areas. This study outlines the noteworthy positive correlation between all the anthropometric factors (weight, BMI) and systolic and diastolic blood pressure except for WC. Many studies have reported positive correlation of BMI with hypertension (systolic and diastolic) [18-20].

No significant association was shown with tobacco and alcohol intake among modifiable risk factors. This is contradictory with other findings where tobacco use alcohol consumption has been found to be associated with hypertension [21-24].

The key point of this study was to presume the prevalence of hypertension and to hit upon associated risk factors in different rural zones of Uttrakhand. This study concluded to bring about the behavior changes and modification in life style so that the prevalence of Hypertension can be reduced in the population.

The study shows that more than $40 \%$ population in our rural area has high BMI. The distressing rates of high BMI and obesity among the population, especially women and youth, signifying where the action plan should be taken. Owing to the effective association of hypertension with lower BMI cutoff value $\left(<23 \mathrm{~kg} / \mathrm{m}^{2}\right)$, this study uses Asian-specific cutoff for the defining levels of overweight and obesity among the population. This calls an in need of awareness and act at the state and also at national level to control the problem of NCD, especially hypertension among Asian countries. 


\section{Limitations}

Lack of specific data on stress levels is a major limitation of the study. Any causal association cannot be derived from the present crosssectional study design. More research with appropriate study design is needed to find if any causal association exists between hypertension and the discussed variables.

\section{ACKNOWLEDGMENT}

This study has received no financial or editorial support.

\section{AUTHOR CONTRIBUTION}

Vinita Thapliyal: Data collection, data analysis, data interpretation, and paper writing. Dr. Karun: Finalization of manuscript. Dr. Anil Joshi: Conceptualization of the Study.

\section{CONFLICT OF INTEREST}

There is no potential conflict of interest involved in this research.

\section{REFERENCES}

1. WHO. The World Health Report 2002: Reducing Risks, Promoting Healthy Life. Geneva: WHO; 2002.

2. Yadav K, Krishnan A. Changing patterns of diet, physical activity and obesity among urban, rural and slum populations in North India. Obesity Rev 2008;9:400-8.

3. Murray C, Lopez AD. The Global Burden of Disease The executive summary of the global burden of disease study, Harvard University Press. Published by: The Harvard School Of Public Health On Behalf Of The World Health Organization And The World Bank. 1996.

4. Government of India. Planning Commission. Ninth Five Year Plan. Vol. 2. New Delhi: Government of India; 2002.

5. Tiwari PC, Joshi B. Environmental changes and status of water resources in Kumaon Himalaya. In: Libor J, Haigh MJ, Prasad H, editors. Sustainable Management of Headwater Resources: Research from Africa and Asia. Tokyo, Japan: United Nations University; 2005. p. 109-23.

6. Thapliyal V, Singh K. "Nutrition transition": A paradigm shift in Uttrakhand. J Nutr Food Sci 2014;4:298.

7. Lee R. The Demographic transition: three centuries of fundamental changes. J Econ Perspect 2003;17:167-90.

8. Amuna P, Zotor FB. Epidemiological and nutrition transition in developing countries: Impact on human health and development. Proc Nutr Soc 2008;67:82-90.

9. Patel MS, Srinivasan M, Laychock SG. Nutrient-induced maternal hyperinsulinemia and metabolic programming in the progeny. Nestle Nutr Workshop Ser Pediatr Program 2005;55:137-47.

10. National Institute of Medical Statistics, Indian Council of Medical Research (ICMR). IDSP Non-Communicable Disease Risk Factors Survey, Phase-I States of India, 2007-08. New Delhi, India National
Institute of Medical Statistics and Division of Non-Communicable Diseases, Indian Council of Medical Research; 2009.

11. Integrated Disease Surveillance Project. Noncommunicable disease risk factors survey Phase-1. Ministry of Health \& Family Welfare, Government of India 2007-08. New Delhi: MoHFW; 2009.

12. Choo V. WHO reassesses appropriate body-mass index for Asian populations. Lancet 2002;360:235.

13. World Health Organization Western Pacific Region, International Association for the Study of Obesity, International Obesity Task Force. The Asia - Pacific perspective: Redefining obesity and its treatment. Sydney, Australia: Health Communications Australia Pty Limited; 2000. Available from: http://www.who.int/nutrition/publications/ obesity/09577082_1_1/en/. [Last accessed on 2006 Aug 23].

14. Dudeja V, Misra A, Pandey RM, Devina G, Kumar G, Vikram NK, et al. BMI does not accurately predict overweight in Asian Indians in Northern India. Br J Nutr 2001;86:105-12.

15. Gus M, Fuchs SC, Moreira LB, Moraes RS, Wiehe M, Silva AF, et al. Association between different measurements of obesity and the incidence of hypertension. Am J Hypertens 2004;17:50-3.

16. James PA, Oparil S, Carter BL, Cushman WC, Dennison-Himmelfarb C, Handler J, et al 2014 evidence-based guideline for the management of high blood pressure in adults: Report from the panel members appointed to the eighth joint national committee (JNC 8). JAMA 2014;311:507-20.

17. Vasan RS, Beiser A, Seshadri S, Larson MG, Kannel WB, D'Agostino RB, et al. Residual lifetime risk for developing hypertension in middle-aged women and men: The Framingham heart study. JAMA 2002;287:1003-10

18. Shahbazpour N. Prevalence of overweight and obesity and their relation to hypertension in adult male university students in Kerman, Iran. Int J Endocrinol Metab 2003;2:55-60.

19. Hsieh SD, Yoshinaga H, Muto T, Sakurai Y, Kosaka K. Health risks among japanese men with moderate body mass index. Int J Obes Relat Metab Disord 2000;24:358-62.

20. Seidell JC, Cigolini M, Deslypere JP, Charzewska J, Ellsinger BM, Cruz A. Body fat distribution in relation to serum lipids and blood pressure in 38-year-old European men: the European fat distribution study. Atherosclerosis 1991;86:251-60.

21. Pandey A, Patni N, Sarangi S, Singh M, Sharma K, Vellimana AK, et al. Association of exclusive smokeless tobacco consumption with hypertension in an adult male rural population of india. Tob Induc Dis 2009:5:15

22. Shanthirani CS, Pradeepa R, Deepa R, Premalatha G, Saroja R, Mohan V, et al. Prevalence and risk factors of hypertension in a selected south Indian population - the Chennai urban population study. J Assoc Physicians India 2003;51:20-7

23. Thomas J, Kakani S. Impact of patient counseling on knowledge, attitude, and practice of hypertensive patients in a tertiary care hospital. Int J Pharm Pharm Sci 2001;9:122-5.

24. Chandra S, Jyothi M. To study the role of exercise and dietary manipulation in obese rats treated with orlistat. Int J Pharm Pharm Sci 2015;7:335-9 